\title{
Evaluating Critical Reflection for Postgraduate Students in Computing
}

\author{
Kay Fielden \\ School of Computing and Information Technology \\ Unitec, New Zealand
}

\section{kfielden@unitec.ac.nz}

\begin{abstract}
In this paper the assumption that critical reflection skills are acquired automatically during postgraduate study is queried by examining whether keeping a reflective journal is an aid in developing reflective habits. All course outlines in the postgraduate program studied for this paper state that students will learn how to critique issues relating to the topic being studied. The assumption is that critical reflection is a skill that is acquired automatically during the degree. Postgraduate students at this particular institution are required to complete a Research Methods course before enrolling in a thesis or dissertation. Research Methods students are encouraged but not required to keep a reflective journal. This paper reports on the effectiveness of keeping a reflective journal by analyzing results obtained over five semesters within the Research Methods course.
\end{abstract}

Keywords: Critical reflection, Postgraduate education, Computing

\section{Introduction}

The challenge addressed in this paper is the assumption that postgraduate students acquire critical reflection skills automatically during their postgraduate studies. In order to address this challenge the final test undertaken by all students in the Research Methods course over five semesters were analyzed.

The Research Methods course in the Masters in Computing degree program is undertaken as the last coursework before students enrol in individual study undertaken as a thesis or dissertation. The thesis attracts half of the credit points for the degree and the dissertation a quarter of the credit points. The Research Methods course is a compulsory prerequisite required before continuing to dissertation or thesis. Inherent in the learning outcomes established for the course is the assumption that critical reflection will be required. There are three assessment items within the course: literature review; research proposal; and reflective test. The reflective test is an ideal means of testing students' own perceptions of how their critical reflection has developed.

In this paper a series of questions are posed about the effectiveness of attempting to teach and evaluate critical reflection explicitly at the postgraduate level. Students undertaking research

methods in the Masters in Computing

Material published as part of this journal, either on-line or in print, is copyrighted by Informing Science. Permission to make digital or paper copy of part or all of these works for personal or classroom use is granted without fee provided that the copies are not made or distributed for profit or commercial advantage AND that copies 1) bear this notice in full and 2) give the full citation on the first page. It is permissible to abstract these works so long as credit is given. To copy in all other cases or to republish or to post on a server or to redistribute to lists requires specific permission from the publisher at Publisher@InformingScience.org degree program were encouraged, but not required, to keep a reflective journal during the semester. Reflective journals were not assessed or evaluated in any way and remained private and confidential to each individual student. Results of the content analysis of the final test of 110 students 
who undertook Research Methods over five semesters are presented with unexpected results.

\section{Reflection}

Going beyond boundary setting of others

Journeying now into inner and still

Feelings recorded shape-shifted in flow

Chasms appearing from anchoring start

Boundary setting of others bridging the gap

Wanderers returning own treasures to share

Heart-rendered accounts - or reports to be scored

Fielden, 2004

Good reflective thinking encompasses a number of levels of activity. At the core of reflection is the notion of awareness of own knowledge, assumptions and past experiences. (Brookfield, 1987) describes reflection as 'the process of hunting out our assumptions and critically examining them'.

(Barnett, 1997) suggests that criticality has the following dimensions: transformational or reconstructive; an understanding of how ideas relate to various traditions; reflexivity or self-reflection; and the discipline or self-monitoring of critical thinking.

Critical reflection therefore is a multi-faceted activity that takes place internally within each person. It involves the ability to look at the self, the self in relation to others and to the world at large. Reflection embraces the ability to 'stand back from the se lf' and examine critically own thinking patterns. Critical reflection also requires an internal honesty and integrity as we examine our own thoughts and assumptions. Critical reflection is necessarily an individual activity initially.

Educators have explored the finer points of becoming a reflective practitioner in attempting to work out the best strategy to encourage students to become reflective practitioners (Atherton, 2002; Brookfield, 1987; Evans, 1997; Goatley, 1999; Hunt, 1997; Imel, 1992; Schon, 1987).

\section{Critical Reflection in Postgraduate Study}

Course requirements at the postgraduate level require students to become 'critically reflective' therefore critical reflection is essential for the successful completion of this particular postgraduate degree in computing. Without critical reflection it appears difficult for students to interpret research findings gained from analysing research data gathered, reading and reflecting on pertinent literature, and self-reflection of their role as researcher in the process of research.

\section{Critical Reflection in this Postgraduate Program}

Learning Outcomes (LO) for the research methods paper are to:

1. Establish the basic requirements for research;

2. Select, analyze, critique and synthesize literature / information pertaining to a potential research topic;

3. Identify and apply methods of formulating solution procedures and construct a draft research proposal; 
4. Experiment with the various techniques used for analyzing quantitative and qualitative observations to establish their appropriateness and limitations;

5. Use a critique of other proposals to improve the initial draft research proposal; and

6. Determine the content and appropriate style of presentation together with the tools used for presenting results.

Critical reflection is an underlying skill required for all learning outcomes, but most particularly for selecting analyzing, critiquing and synthesizing (LO2).

\section{Literature Review}

A common feature of higher education learning support centers is a series of helpful hints on how to keep a reflective journal. For instance, on the University of Technology Sydney's learning centre website hints given are: recording events and results and reactions to these; data upon which to base reflective discussion; opportunities to challenge the self; impetus to take informed action; and a means of developing a personal philosophy. This is a diverse range of reflective abilities according to the 5-stage reflective model (Bain, Packer, \& Mills, 1999) represented in Table 1.

Brookfield (1987) suggests that the core properties of critical thinking are: to identify and challenge assumptions, and to imagine and explore alternatives. He also suggests that the processes of critical thinking are: person specific - people vary greatly according to personality, culture and gender; dependent on emotions - emotional releases are central to challenging assumptions - both intrinsic and extrinsic; unexpected or insightful (and this may happen long after the period of instruction); and that peer support is crucial for critical thinking skills to mature. Brookfield also believes that there is no standard model for facilitating the development of critical thinking and that diversity of methods and material is required. He states that it is important to learn to accept imperfections of self and others in developing critical thinking. He also believes that critical thinking often only happens after a period of frustration and struggle.

Evans (997) states that 'reflective practice' offers a highly challenging paradigm of learning. He suggests that learning to derive abstract generalizations from specific practices, events or thoughts is inductive learning; which is diametrically opposed to the dominant paradigm of deductive learning.

Hunt (1997) describes the 'felt reality' of 'doing reflective practice'. A most insightful comment from Hunt is: ' ...often, though, I realize that I am the only person who already holds the key to understand why I have initially interpreted and reacted to a situation in my professional practice in a particular way - but in order to find it I will have to look into the shadows of my own mind." Hunt believes that we must be willing to cross and re-cross consciously the borders in our minds between the light of what is already known and the shadows where ideas, thoughts and connections lie hidden or at best, only dimly perceived. Such crossing and re-crossing involves changing perspectives of the self and the relationship of the self to the outer world.

Re-crossing mind borders is often a painful and messy business easily lost in busy lives. Most postgraduate students belong to one of the following groups: part-time, mature and balancing family, work and study; or full-time and studying in English as a second language away from family and own culture. In both cases their lives invariably have conflicting demands on time and intellect. In both cases there is considerable self-discipline required to form the habit of keeping a reflective journal.

A major dilemma is that the final product of this reflective practice for the Masters in Computing is a dissertation or thesis. Such documents are required to be written in an academic language that 
is highly stylized and uses English in a unique manner that is formalized and rigidly expressed, whereas reflective writing tends to be subjective, informal and expressed creatively.

Hunt also suggests that encouraging students to become reflective practitioners is about 'holding the learning space' from which they start on their personal reflective journeys. She also suggests that giving feedback on reflective practice should be sensitive to the intensely personal journey of each individual student. Teaching students to become reflective practitioners is also about keeping organizational boundaries and maintaining a home base. There is a dilemma here - organizational writing and writing styles is about as far from critical reflection writing as you can possibly get. (Imel, 1992) suggests that reflective practice is a mode that integrates or links thought and action with reflection.

Bain et al. (1999) suggest that there are 5 levels of reflection (Table 1). Reporting, at level 1 is description, reporting or re-telling of events with no added observations or insights. Level 2 described by Bain et al as 'responding' is the reporting of emotion and judgment without comment made with little transformation of conceptualization. Level 3 or relating, is described by Bain et al as demonstration of the ability to relate items recorded to personal experience, an understanding of relationships between concepts, identification of own strengths or mistakes and knowing that something needs to be changed. Level 4 or reasoning, is attained when data integration into appropriate relationships theoretical concepts, personal experience, high level of transformation and conceptualisation is evident in reflective practices. Students seek a deep understanding of why something has happened, explore or analyze a concept, event or experience, asks questions and look for answers, consider alternatives, or speculate or hypothesize about why something is happening. Explanations of own or others' behaviour or feelings are sought at level 4 based on own insight, inferences, experiences or previous learning. It is at level 4 that the relationship between theory and practice is explored in some depth. Level 5 or reconstructing, is reached when there are displays of high level abstract thinking, generalizations and/or application to learning. Original conclusions are drawn from own reflections, generalizations from experience, extraction of general principles, formulation of personal theory are evident in students' reflective practice. Students extract and internalize the personal significance of learning and/or plan further learning on the basis of reflections.

Table 1: 1 Five-point level of reflection scale (Bain et al, 1999)

\begin{tabular}{|l|l|}
\hline \multicolumn{1}{|c|}{ Level } & \\
\hline Reporting & Student describes, reports or re-tells with no added observations or insights \\
\hline Responding & $\begin{array}{l}\text { Source data used with little transformation or conceptualisation } \\
\text { Student makes an observation or judgement - no reasons given, 'rhetorical' questions - but no alterna- } \\
\text { tives } \\
\text { Student reports a feeling such as relief, anxiety, happiness, etc. }\end{array}$ \\
\hline Relating & $\begin{array}{l}\text { Aspects of data identified that have personal meaning or connect with experience. } \\
\text { Student seeks a superficial understanding of relationships. } \\
\text { Student identifies own strengths, improvements, mistakes or experiential learning } \\
\text { Superficial explanation for reason why something has happened } \\
\text { Identification of something they need or plan to do or change. }\end{array}$ \\
\hline
\end{tabular}




\begin{tabular}{|c|c|}
\hline Reasoning & $\begin{array}{l}\text { Data integration into appropriate relationships theoretical concepts, personal experience, high level of } \\
\text { transformation and conceptualisation. } \\
\text { Student seeks a deep understanding of why something has happened. } \\
\text { Student explores or analyses a concept, event or experience, asks questions and looks for answers, } \\
\text { considers alternatives, speculates or hypothesises about why something is happening. } \\
\text { Student attempts to explain own or others' behaviour or feelings using own insight, inferences, experi- } \\
\text { ences or previous learning, with some depth of understanding } \\
\text { Student explores the relationship between theory and practice in some depth. }\end{array}$ \\
\hline $\begin{array}{l}\text { Reconstruct- } \\
\text { ing }\end{array}$ & $\begin{array}{l}\text { Student displays high level of abstract thinking to generalize and/or apply learning. } \\
\text { Student draws an original conclusion from their reflections, generalizes from their experience, extracts } \\
\text { general principles, formulates a personal theory of teaching or takes a position on an issue. } \\
\text { Student extracts and internalises the personal significance of their learning and/or plans their own fur- } \\
\text { ther learning on the basis of their reflections. }\end{array}$ \\
\hline
\end{tabular}

Common tools utilized for teaching critical reflection include a reflective journal (Goatley, 1999; Hunt, 1997; Imel, 1998; Schon, 1987; Stein, 2000), the use of dialogue in small groups (Boys, 1999; Brookfield, 1987), practice-based assignments (Boud, Keogh, \& Walker, 1995; Evans, 1997) and learning as narrative process (Umphrey, 2004). It is only the skills acquired during the process of keeping a reflective journal that are considered in this paper.

\section{Research Questions}

In attempting to understand how postgraduate students become critical practitioners the following research questions were posed:

- Can Critical Reflection be taught?

- If Critical Reflection can be taught how can it be evaluated?

- Is a reflective journal an appropriate tool to reinforce critical reflection skills for postgraduate students?

- Is a reflective test an effective way of evaluating critical reflection for postgraduate students?

\section{Research Method}

Having taught this paper for five semesters and observed how difficult it is for students to develop critical reflection skills, I decided to analyze the reflective tests from the end of each semester. Even although the course is delivered inductively and reflectively emphasizing underlying philosophical approaches to research in computing it did not appear that critical reflection was skill that could be taught inductively or by example. Each semester the students took part in a reflective test. An example question is shown in Figure 1. Whilst there were no direct questions on keeping a reflective journal, each test had questions that required the student to consider what it meant to keep a reflective journal. Hence, content analysis was applied to the tests accumulated over 5 semesters to extract the responses that related to issues involving research journals. All students who have undertaken the research methods paper in this particular postgraduate degree were encouraged to keep a reflective journal and all students were evaluated with a reflective test at the end of each semester. A bank of reflective questions has been developed for these tests and each semester the questions are changed. Direct questions on critical reflection are not asked rather the questions are designed so that students can demonstrate their reflective abilities. For instance in analyzing the question shown in Figure 1 one student described the way in which keeping a journal had helped them to monitor and control research activities. Another student 
Question 3

[Total 10 marks]

Research Process

a. Describe briefly three important factors required to control and monitor research process.

1.5 marks

b. List all the ways in which you controlled and monitored your research process in Research Methods this semester.

5 marks

c. Describe briefly how the ways in which you controlled and monitored your research process helped you to develop your researching ability.

2.5 marks

d. Discuss briefly how the ways in which you controlled and monitored your research process could be improved.

1 mark

Figure 1: A Test Question

stated that keeping a reflective journal helped to "meet deadlines and to monitor research progress".

\section{Data Collection}

110 reflective tests over five semesters were analyzed to find out whether the students believed that critical reflection was a core research skill and whether they stated and commented on keeping a research journal.

\section{Data Analysis}

43/110 students stated explicitly that they believed it was important to keep a critical reflection journal (Table 2). 28 of these 43 students reported in the test that they had formed the habit of keeping a journal. 3 students stated that they were forming the habit, one had 'started' to keep a journal and 8 had not kept a journal - although they reported that 'keeping a journal is a good idea'.

\begin{tabular}{|c|c|c|c|c|l|l|c|}
\hline \multicolumn{2}{|l|}{ Table 2: Journal keeping, habit forming, and Bain et al's (1999) reflection levels } \\
\hline $\begin{array}{l}\text { Level/ } \\
\text { Response }\end{array}$ & $\begin{array}{l}\text { Journal/ } \\
\text { Habit } \\
\text { Formed }\end{array}$ & $\begin{array}{l}\text { Journal/ } \\
\text { Habit } \\
\text { Forming }\end{array}$ & $\begin{array}{l}\text { Journal/ } \\
\text { Habit } \\
\text { Started }\end{array}$ & $\begin{array}{l}\text { Notes/ } \\
\text { Habit } \\
\text { Formed }\end{array}$ & $\begin{array}{l}\text { Notes/ } \\
\text { No } \\
\text { Habit }\end{array}$ & $\begin{array}{l}\text { No } \\
\text { Journal/ } \\
\text { No } \\
\text { Habit }\end{array}$ & Total \\
\hline Nothing & 0 & 0 & 0 & 0 & 1 & 5 & $\mathbf{6}$ \\
\hline Reporting & 7 & 1 & 2 & 1 & 0 & 0 & $\mathbf{1 1}$ \\
\hline Responding & 11 & 0 & 0 & 0 & 0 & 1 & $\mathbf{1 2}$ \\
\hline $\begin{array}{c}\text { Relating } \\
\text { Reasoning }\end{array}$ & 2 & 2 & 0 & 0 & 0 & 0 & $\mathbf{8}$ \\
\hline $\begin{array}{c}\text { Reconstruct- } \\
\text { ing }\end{array}$ & 2 & 0 & 0 & 0 & 0 & 1 & $\mathbf{3}$ \\
\hline Total & $\mathbf{2 8}$ & $\mathbf{3}$ & $\mathbf{2}$ & $\mathbf{2}$ & $\mathbf{1}$ & $\mathbf{7}$ & $\mathbf{4 3}$ \\
\hline
\end{tabular}


According to Bain et al. (1999) 5 point reflection level scale (Table 2) those students who did not keep a journal - but knew it was a 'good idea' had not even reached level 1 - reporting - on this scale. From this particular sample 30/ 110 students achieved some level of reflection once the habit was formed. Being aware that it is a good idea to keep a journal - but not doing it is not conducive to developing critical reflection skills. 6/43 students were in this category. 67/110 however did not even report that keeping a journal was important. Most high achievers in research methods reported that keeping a journal was important to develop critical reflection skills. There are anomalies in this sample - 1 student who achieved level 5 (reconstruction) who did not keep a journal - but who had kept research notes; and 1 student who had not formed the journal habit and also achieved level 5 on Bain et al's scale.

\section{Does the Reflective Test Evaluate Critical Reflection Skills Effec- tively?}

According to feedback from students, they believe that keeping a critical reflection journal certainly helped them to:

- Pass the Research Methods reflective test;

- Equipped them with appropriate critical thinking skills to complete a thesis or dissertation;

- Helped them to acquire life-long learning skills;

Students believe that they could not have completed the test successfully if they had not kept a journal.

Students who did not heed the advice to keep a reflective journal said that it affected their marks in the test. More importantly, these students did not acquire critical reflection skills.

Because journal-keeping was a voluntary activity and not assessable it is unlikely that responses given in the test were 'for marks only'. It is much more likely that what was reported did indeed take place. Observation during the semester with class sizes that ranged from 10 to 34 it was possible to gauge how students were developing their critical reflection.

\section{Emergent Results}

Besides demonstrating the vital role of keeping a reflective journal, this research has shown that a reflective test can provide the opportunity for students to debrief during this final test. Students wrote in the test that they appreciated the opportunity to "write things down and to say what was really important to me'. Not only did the test provide a time and a place to debrief, it also provided an opportunity to demonstrate the level of critical reflection achieved as perceived by the students.

The test viewed as a debriefing device provided the students with the opportunity to complete the learning process in the same semester. Many times a test leaves students with a sense of incompletion, that the process stopped midway, and that the students still needed to talk about what had happened. None of the literature reviewed employed the research methods utilized in this case study. None of the esteemed educators exploring the issues surrounding the acquisition of critically reflective skills performed content analysis on a reflective test. Therefore it is difficult to compare the results gained in this study with prior research results.

I am still no clearer about whether critical reflection can be taught. I think that clear boundaries and environment setting are more important than 'teaching'. (Stein, 2000) also believes 'how to teach different levels of critical reflection 'is still in need of additional research'. Stein also suggests that the effectiveness of commonly employed methods to teach critical reflection like journal-keeping is unclear. 


\section{My Reflections on Analyzing the Tests}

When I reflected on the research questions posed:

- Can Critical Reflection be taught?

- If Critical Reflection can be taught how can it be evaluated?

- Is a reflective journal an appropriate tool to reinforce critical reflection skills for postgraduate students?

- Is a reflective test an effective way of evaluating critical reflection for postgraduate students?

I realized that I had not answered these questions directly by analyzing the students' reflective tests. I still do not know whether the reflective test is an appropriate evaluation tool. What I do know is that it gave the students an opportunity to debrief a semester's learning, development and skills acquired. Because $61 \%$ of the students did not include responses relating to keeping a journal I cannot answer this question. I am still not sure whether critical reflection can be taught. For the majority of students who did acquire the habit of keeping a research journal they did achieve a score on Bain et al's scale (1999). For those who did not report anything about journal keeping, their tests did not convey any level of critical reflection from this content analysis. It does not appear from this particular sample that critical reflection is gained by students in a class where critical reflection is demonstrated and role-modeled. My intuition suggested that this would be the case. 'Holding the boundaries' Hunt's (1997) was certainly practiced in this paper. Because it was not stated it was not in the students' conscious awareness and therefore not something that could be addressed in a test whether it was reflective or not.

My expectations before I analyzed the tests were that most of the students would have developed critical reflection skills by the time they sat the final test. What actually happened was quite different. Only $28 \%$ reported any level of reflection and only $3 \%$ achieved level 5 (reconstruction).

It appears therefore from this sample of 110 postgraduate students that learning to keep a critical reflection journal is not an automatic skill that can be acquired over one semester. One student reported (a year after completing research methods) that she only started to keep a journal when she really needed it - when she was doing her thesis.

It seems important to recognize that to acquire critical reflection in research is a skill that matures as the researcher gains competence, experience and maturity. Even although I still do not know whether critical reflection can be taught, it seems to be important that acquiring critical reflection skills develops and matures with time and practice. Keeping a reflective journal starts the practice. Introducing critical reflection is important in the research methods course. It is however important to realize that students acquire critical reflection in their own time. There appears to be a link between keeping a critical journal regularly and developing critical reflection as a skill. Those students who did not keep a journal (67\%) did not achieve a reflection score on Bain et al's (1999) scale.

Initially this was a disappointing result, especially when critical reflection skills had been taught and reinforced in both assignment work and the final test. The subsequent realization is that critical reflection cannot be taught in one 'hit'. This cohort of students was developing critical reflection skills at their own pace as indicated in Table 2.

\section{Implications}

It seems to me that as a postgraduate educator I know very little about how to encourage students to develop their own critical reflection skills and practice. I can encourage, role-model, demonstrate, provide exercises, give feedback and test whether students can show they know what criti- 
cal reflection is. But because the development of critical reflection is such an individual and personalized skill and practice, I do not know what is going on inside in each student's head. It seems to me that the best I can do is to know more about how I interact with students as they develop individually on their reflective journey; to know when to encourage and when to stand back; when to allow students to falter and when to direct a course of action. The relationship between critical reflection skills and rationality required in the rest of the research process is something that requires further examination. Hunt (1997) and Stein (2000) are in agreement that we venture in murky grounds when we explore the domain between critical reflection and rationality. Some authors (Hunt, 1997; Imel, 1998; Stein, 2000) also believe that the journey to becoming critical reflective is one that ventures onto paths that neither educator or student may ever have been before. For some, this journey can be traumatic.

Contrary to the external monitors' suggestions (Unitec Masters in Computing program monitor's report, 2002) that the reflective test was not an appropriate evaluation tool for a research methods paper, my experience over 5 semesters has demonstrated effectiveness well. The unexpected outcome that the test was also a debriefing device provided a sense of completion to the learning process for the students involved. Concentrating on elements of the research process rather than mechanistic research skills has encouraged and reinforced students' critical reflection skills to progress up the reflection skill ladder (Bain et al., 1999).

\section{Conclusion}

Keeping a reflective journal appears to be an essential element for most students in this sample as they become postgraduate researchers. If students keep a reflective journal then they will start on their individual journey towards becoming a researcher. If they do not keep a reflective journal it is highly unlikely that critical reflection skills will develop automatically. It seems such a simple and logical solution to improving pass rates at the postgraduate level - but it is not. Critical reflection skills are individual, emotionally-charged, and highly personal. It requires gentle but firm direction to transform personal reflection into academic outputs. Most of us stumble when we are required to be gentle but firm with our students.

\section{References}

Atherton, J. (2002). Learning and teaching: Reflective practice. Retrieved 8 October 2003 from http://www.dmu.ac.uk/ jamesa/learning/reflecti.htm

Bain, R., Packer, J., \& Mills, C. (1999). Using journal writing to enhance student teachers' reflectivity during field experience placement. Teachers and Teaching: Theory and Practice, 5 (1), 51-73.

Ballantyne, R., \& Packer, J. (1995). Making connections: Using student journals as a teaching/learning aid. HERDSA, ANU.

Barnett, R. (1997). A critical business. SRHE and Open University. Buckingham. http://www.critical.sotol.ac.uk/ros\%20\&\%20brenda\%20seminar..htm

Boud, D., Keogh, R., \& Walker, D. (1995). Reflection: Turning experience into learning. London: Kogan Page.

Boys, M. C. (1999). Engaged pedagogy: Dialogue and critical reflection,. Teaching Theology and Religion. Retrieved 3 February 2005 from http://www.prsltsn.leeds.ac.uk/relig_studies/reviews/ttr2_3_1999 boys.html

Brookfield, S. D. (1987). Developing critical thinkers: Challenging adults to explore alternative ways of thinking and acting. San Francisco: Jossey-Bass.

Evans, D. (1997). Reflective learning through practice-based assignments. Education-Line. Retrieved 8 October, 2003 from http://www.leeds.ac.uk/educol/documents/000000468.htm 
Goatley, R. (1999). Developing skills of reflection. Hatfield: Dept of Health and Social Care, University of Hertfordshire.

Hunt, C. (1997). Shadows in the swamp: dialogues in reflective practice. Education-Line. Retrieved 8 October, 2003, from http://www.leeds.ac.uk/educol/documents/000000247.htm

Imel, S. (1992). Reflective practice in adult education. ERIC Digest, 122.

Imel, S. (1998). Teaching critical reflection. ALERTS, Trends and Issues, ERIC Clearinghouse on Adult, Career and Vocational Education.

Schon, D. (1987). Educating the reflective practitioner. San Francisco: Jossey-Bass.

Stein, D. (2000). Teaching critical reflection: Myths and realities. ERIC Clearinghouse on Adult, Career and Vocational Education.

Umphrey, M. L. (2004). Learning as a narrative process. Retrieved from http://www.edheritage.org/tools/alert.htm

\section{Biography}

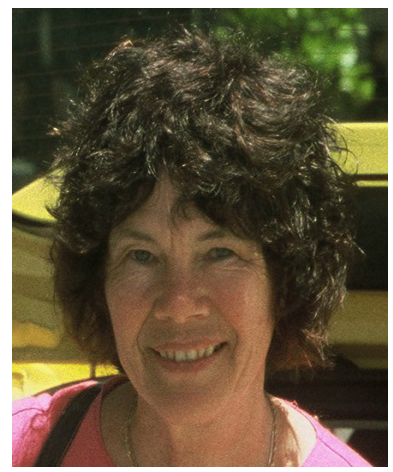

Kay Fielden is the Research Co-ordinator for the School of Computing and Information Technology at Unitec New Zealand. She teaches research methods to postgraduate students within the School of Computing and Information Technology, supervises at the postgraduate level and mentors staff within the school for their research requirements. Kay has been an academic for more than 20 years and has developed wide interests in researching, teaching and consulting within the field of computing. 